\title{
The Digitization of Web-based Music Theory Modules
}

\author{
Lingga Ramafisela \\ Departement of Music Education, ISI Yogyakarta, Yogyakarta, Indonesia \\ email: linggaramafisela@gmail.com
}

\section{A R T I C L E I N F O \\ Article history: \\ 1 Agustus 2020 Received in revised form \\ 20 September 2020 \\ Accepted 10 November 2020 \\ Available online 20 \\ November 2020 \\ Kata Kunci: \\ Digitalisasi, Modul, Teori \\ Musik, Web \\ Keywords: \\ Digitization, Module, Music \\ Theory, Web.}

\begin{abstract}
A B S T R A K
Pada era digital, modul yang berbentuk buku dirasa kurang efektif dan tidak efisien karena adanya tuntutan perkuliahan secara daring dan mandiri. Hal ini ternyata menemui kendala karena keterbatasan media pembelajaran. Modul digital diperlukan untuk menunjang kegiatan belajar mengajar mata kuliah teori musik agar materi yang disampaikan dapat terintegrasi dengan baik. Digitalisasi merupakan proses adanya perubahan dari media cetak menjadi media berbentuk elektronik. Oleh sebab itu perlu dilakukan digitalisasi modul teori musik berbasis web yang bertujuan untuk memudahkan proses belajar mengajar. Digitalisasi modul teori musik berbasis web dapat menjadi komponen penting yang mendukung terlaksananya program kuliah daring yang sedang dicanangkan pemerintah saat ini serta mendukung gerakan ramah lingkungan (paperless). Target yang ingin dicapai selanjutnya adalah pengembangan modul teori musik berbasis web pada program studi Pendidikan Musik ISI Yogyakarta. Metode kualitatif digunakan dalam penelitian ini berdasarkan data yang diperoleh di lapangan, yaitu di kelas teori musik program studi Pendidikan Musik ISI Yogyakarta. Teknik pengumpulan data yang dilakukan yaitu dengan cara studi pustaka, observasi,
\end{abstract} serta wawancara. Proses analisis data dilaksanakan dengan mereduksi data, penyajian data, dan penarikan kesimpulan. Keberadaan modul teori musik berbasis web diharapkan dapat berg. una untuk kemudahan, kemajuan serta efektivitas kegiatan belajar mengajar. Hasil penelitian ini menunjukkan bahwa modul tersebut memenuhi kriteria tertentu, seperti instruksional mandiri, mandiri, mandiri, adaptif, dan ramah pengguna. Berdasarkan hasil penelitian dapat disimpulkan bahwa digitalisasi modul teori musik berbasis web merupakan salah satu bukti transformasi digital akibat kemajuan teknologi.

\begin{abstract}
A B S T R A C T
In the digital era, modules in the form of books are deemed ineffective and inefficient due to the demand for online and independent lectures. This turned out to be facing obstacles due to limitations in learning media. Digital modules are needed to support teaching and learning activities in music theory courses so that the material presented can be well integrated. Digitalization is the process of changing from printed media to electronic media. Therefore it is necessary to digitize the webbased music theory module which aims to facilitate the teaching and learning process. The digitization of web-based music theory modules can be an important component that supports the implementation of the online lecture program that is currently being proclaimed by the government and supports the environmentally friendly (paperless) movement. The next target to be achieved is the development of a web-based music theory module in the ISI Yogyakarta Music Education study program. The qualitative method used in this research is based on data obtained in the field, namely in the music theory class of the ISI Yogyakarta Music Education study program. The technique of collecting data is utilizing literature study, observation, and interviews. The data analysis process was carried out by reducing data, presenting data, and drawing conclusions. The existence of a web-based music theory module is expected to be useful. una for convenience, progress and effectiveness of teaching and learning activities. The results of this study indicate that the module meets certain criteria, such as independent, independent, independent, adaptive, and user-friendly instructional. Based on the research results, it can be concluded that the digitization of the web-based music theory module is one proof of digital transformation due to technological advances.
\end{abstract}

\section{Introduction}

The fundamental of music lessons is musical theory. It is a set of theories that can be used to perceive music. The material within music theory lessons includes the understanding of musical notations, scales, time signatures, cadences, chords, intervals, and many more. Musical theory is the most important thing to master before getting to know other musical mastery, for instance, a solfeggio, harmony, counterpoint, manual of harmony, and musical instrument practice. Music theory is an absolute material that must be acquired by students.

To date, music theory courses in the Department of Music Education of ISI Yogyakarta have been supervised by several lecturers with expertise in music theory. They make use of modules in the form of 
textbooks written by each of the lecturers. The modules are compiled in such a way to help the students understand the learning material. Lecturers who are in charge of music theory courses perform distinctive styles in delivering the material. The use of music theory modules is pretty much helpful to make the students comprehend the musical theory. On the other hand, there appears a number of problems during the class, for example, the students often do not bring the modules and the material that is delivered during the parallel class cannot be the same occasionally. As a consequence, the learning processes are worth the hassle, quite inefficient, and ineffective.

Current situation hitting the country forces all teaching-learning activities to be done online and autonomously. The common obstacle faced by students during online classes is that they hardly grasp the material delivery due to the lack of learning media. Unlike an offline meeting, an online class needs fast, precise, and practical solutions. In the millennial era, the presence of digital modules is a necessity to support the teaching-learning activity. Digital module is a module in a digital form. The digitization of The Great Dictionary of the Indonesian Language (Kamus Besar Bahasa Indonesia) is the process of giving and using digital systems (Setiawan, 2019). Digital modules can systematize all music theory modules in the Department of Music Education by digitizing them into web-based digital modules. The digitization of the web-based music theory modules aims to facilitate and accelerate the teaching and learning process in the Department of Music Education as it can be accessed through the web and updated quickly. This is one of the evidence of scientific and technological developments in the socio-cultural field. Digital technologies are increasingly important to create and maintain social contacts (Beaunoyer et al., 2020). Digital transformation is defined as the transformation of business process, culture, and organizational aspects to meet market requirements, owing to digital technologies (Nasiri, M., Ukko, J., Saunila, M., Rantala, 2020). Digitization is important challenge in creating interactive, digitalized platforms, and digital activities that meaningfully engage students (Crittenden et al., 2019). Students derive direct benefits from this, for instance, they can learn and work on assignments through the web whenever they are. Not only students but the digitization of modules can also put the lecturers at ease in the material delivery. Additionally, digital music theory modules support environmental sustainability because they reduce paper usage or are eco-friendly and efficient. The modules also have an up-to-date and appealing user interface which can boost the students' enthusiasm in learning music theory.

A module must own several characteristics to make it usable for what it is. Those characteristics include self-instructional, self-contained, stand-alone, adaptive, and user-friendly (Lestari, 2013). First, self-instructional means a module must contain clear objectives and be able to make the students learn autonomously to build the self-instructional character. Furthermore, a module which agglomerates many learning materials into more specific sub-chapters will help the students to learn in sequence and profoundly. Second, self-contained denotes that all learning materials must be arranged systematically so that they can become a complete and perfect handbook. Therefore, all materials must be compiled in one module as a whole to make it easier for users or readers to understand. Third, stand-alone suggests that a module must not depend on another module. Hence, it is inferred that the module can be used all alone without using other modules. Fourth, adaptive means a module must highly absorb the advancement of science and technology. A module will be much greater if it contains materials regarding the evolution of modern science and technology that broaden students' knowledge. The last is user-friendly which means every instruction and explanation as well as information must be pronounced, helpful, and simple to use. It also has to accommodate the users to access and give responses in accordance with his/her desire. Therefore, a module should be structured to make it easier for users, especially students, to obtain unambiguous information. The digitized music theory modules in a form of web need to cover up characteristics mentioned above.

Digitization refers to a changing in media types from a printed text, audio, or video into digital forms and also a transfer of media from printed forms to electronic or digital forms (Asaniyah, 2017). According to Bloomberg, digitization corresponds to an interaction that alters analog technology, for example, digital phone calls through an email, social media, and chatting platform (Bloomberg, 2018). Digitization is the transfromation from analog to digital data (Ritter, T., Pedersen, 2020). Digital technologies have become a prominent vector of communication, interactions, and participation between citizens and societal entities in many countries (Baum et al., 2014). Digital formats decrease the cost and time required to organize academic interactions and diminish food, plastic, and paper wastes (Schwars, 2020).

Web is a collection of pages displaying any information and data in the forms of texts, pictures, animations, voices, videos, and a combination of static or dynamic data that are interconnected to other electronic documents or web pages (hyperlink) (Hariyanto, 2015). Meanwhile, a website represents the entire web pages containing an abundance of information and accessed via a domain (Yuhefizar, 2012). Website is a term for a set of web pages which is generally identified by a domain or subdomain on the World Wide Web (WWW) (Harminingtyas, 2014).

The previous study mentioned that teaching materials was a set of material that used by lecture to achieve the expected goals in learning. Teaching material used by lecture to deliver the material that arranged in 
systematic, well-organized, method, and exercise to practice the skills but this study is slightly different from the research that will be conducted, namely that the module presented is not web-based (Ruhiat \& Djumena, 2019). Other study mentioned that the development of music theory module was an urgency because of this material was a fundamental to students to pass the next materials, so that it was necessary to develop the module that attractive, systematic, constructive and familiar with students' lifestyle nowadays. This discussion is only about the music theory material module in printed form (Putra et al., 2019). The other study mentioned that the use of online learning resources was not only beneficial because of its interactivity and accessibility but increase the indepence to the students. This article is about a web-based module but not a music theory module (Suryoso, 2014). Therefore, the aims of the research are to know the effectiveness of the digitization of web-based music theory modules in the Department of Music Education of ISI Yogyakarta.

\section{Method}

Research method is a scientific activity that is done in stages starting from selecting a topic, gathering the data, and analyzing the data to acquire a complete understanding of a certain topic, phenomenon, or issue (Raco, 2010). This research employs the qualitative method. It is also known as an artistic method because it portrays the nature of arts and is also known as an interpretative method as the research results intersect with the researchers' interpretation of the data found in the field (Sugiyono, 2014). Qualitative research is an approach that allows you to examine people experiences in detail by using a specific set of research methods such as in depth interviews, forum group discussion, observation, content analysis, visual methods, and life histories or biographies (Hennink, M., Hutter, I., Bailey, 2020). Qualitative research methods are designed in a manner that help reveal the behavior and perception of a target audience with reference to a particular topic (Bhat, 2016). The researcher not only uses a qualitative method but also a descriptive analysis to give clear and detailed pictures of the data and situation to produce a systematic conclusion. The object material of the research is web-based music theory modules in the Department of Music Education of ISI Yogyakarta. Students and lecturers of music theory classes in the Department of Music Education of ISI Yogyakarta become the research subjects. The qualitative method is utilized to know how effective the digitization of web-based music theory modules is.

The data gathering techniques include library research, observation, and interview. The library research includes reading through both online and printed books, journals, articles, and other references related to the digitization of web-based music theory modules. Well-grounded information and data sources are obtained after doing library research. An observation or field investigation is a data-gathering technique that is more distinctive than others. Observation is the systematic description of the events, behaviors, and artifacts of a social setting (Marshall \& Rossman, 1999). In this research, the type of field investigation done by the researcher is participant observation. Participant observation involves being in the setting under study as both observer and participant (Kawulich, 2005). The researcher directly involves in the investigation to have a first-hand insight of music theory modules that would be digitized into web-based modules and to communicate with students as the users of the modules in person. Twenty students who take the music theory class become the research subjects. Moreover, the observation is conducted on campus and the researcher's place virtually. Interview is another data collection method to augment more specific, focused, and overarching information and to complement data from previous informants. The interview questions are designed to get systematic answers. The researcher combines structured and unstructured interviews during the interview process. The interviewees are students and lecturers of music theory classes in the Department of Music Education of ISI Yogyakarta. The interview questions are about the effectiveness and benefit of web-based music theory modules.

The data analysis is done upon the completion of the data gathering process. There are several steps in analyzing the research data. First, data reduction. Data reduction can be interpreted as a process of summarizing, selecting cores and important data, and searching for themes and patterns. Hence, data that are reduced will give more definite and tangible research findings. The data will also put the researcher at ease in further data collection (Sugiyono, 2014). In this research, the data are obtained from the observation and interview with students and lecturers of music theory classes. Second, data presentation. This step is performed after data reduction. Data presentation is useful for connecting existing data to make them well-organized and understandable. There a number of data gained from the observation of students and interview with both students and lecturers of music theory classes. Those data are related to the benefit of web-based music theory modules. Third or last, Conclusion. This step is sourced from the data that have been analyzed. Data will then be processed in a structured manner using a certain approach. Further, the researcher draws conclusions from the research. From the data analysis, it can be concluded that the digitization of music theory modules has positive impacts on students and lecturers of music theory classes.

\section{Result and Discussion}


The digitization of web-based music theory modules done in the Department of Music Education of ISI Yogyakarta is a form of technology development in education and teaching fields. This is related to the change or transfer of the media used in the music theory learning process. The music theory modules are in the form of a book. The technological advancement and era of innovation urge people to make changes in the learning system to make it more effective and efficient. The digitized music theory modules are products of technological development that support learning processes in the Department of Music Education of ISI Yogyakarta. Webbased music theory modules offer a bunch of merits for students and lecturers of the music theory subject. One of the merits is that students can learn wherever and whenever they want to use their gadgets. Furthermore, in this current situation, schools still continue to educate students through online education and distance learning. Digital literacy appears to focus most intently on digital technologies (Pangrazio et al., 2020).

As mentioned before, a module must fulfill particular criteria, such as self-instructional, self-contained, stand-alone, adaptive, and user-friendly. Web-based music theory modules are designed as best it could to cover up all criteria. In terms of self-instructional, the web-based modules are developed and designed by formulating learning objectives and presenting learning materials in more specific and intelligible ways. Self-contained is noticeable in the digital transformation from print to web-based learning modules. Regarding stand-alone, this web focuses on music theory only and does not rely on other materials. Fourth, web-based music theory modules are adaptive as it verily adapts to the development of science and technology. Meanwhile, a user-friendly criterion is reflected through the web-based music theory modules' ease of access. Every single instruction is designed to make users easier to access the information because it can be accessed from phones. The web will help students deal with online learning challenges.

The process of creating the web as the platform of digitized music theory modules. The phases of the web design are as follows : 1) Determining the theme, concept, and feature of the website (based on the information purpose of the website). This step is following the purpose of the web design which is as the digital platform of music theory modules; 2) Designing a layout or graphic of the web (ensuring or choosing the programming language that will be used to design the website layout or template). This step is done by deciding what kind of website layout that will be displayed. A programming language can be adjusted afterward to create templates and graphics for the website; 3) Creating a website system or CMS platform (ensuring or choosing a programming language that will be used to design website frameworks and decide the database). CMS is a system that consist of combination from range of subject management tools to provide means from online virtual learning environment (Lust et al., 2012). Content Management System (CMS) is an information system that allows publishing, editing, modifying content over internet through a central interface (Oztaysi, 2014). the importance of CMS has increased dramatically in recent years (Yen, Chia-Chen., Yen, C., Hsu, 2008). Web system is an important component of a web. It requires a programming language which later is used to create web frameworks and to decide the database. The CMS to be an electronic information system including webbased systems that enable storage, organisation, management and export of content from a single source (Reddy et al., 2017); 4) Choosing the web hosting to publish the website that has been created and Domain Name Service (DNS). Web hosting is a service that allows organizations and individuals to post a website or web page onto the internet. A web host or web hosting service provider, is a business that provides the technologies and services needed for the website or webpage to be viewed in the internet (Website.com, 2019). Domain Name Server or DNS is a system that connects Uniform Resource Locator (URL) and Internet Protocol Address/ IP Address (Indra, 2019) and domain names is the addres every site visitor will type in to visit your website (Brown, 2010). The web hosting and DNS is used to publish the web that has been made as to the realization of digitized music theory modules. The following is the display of the digitized music theory modules that have been created. 


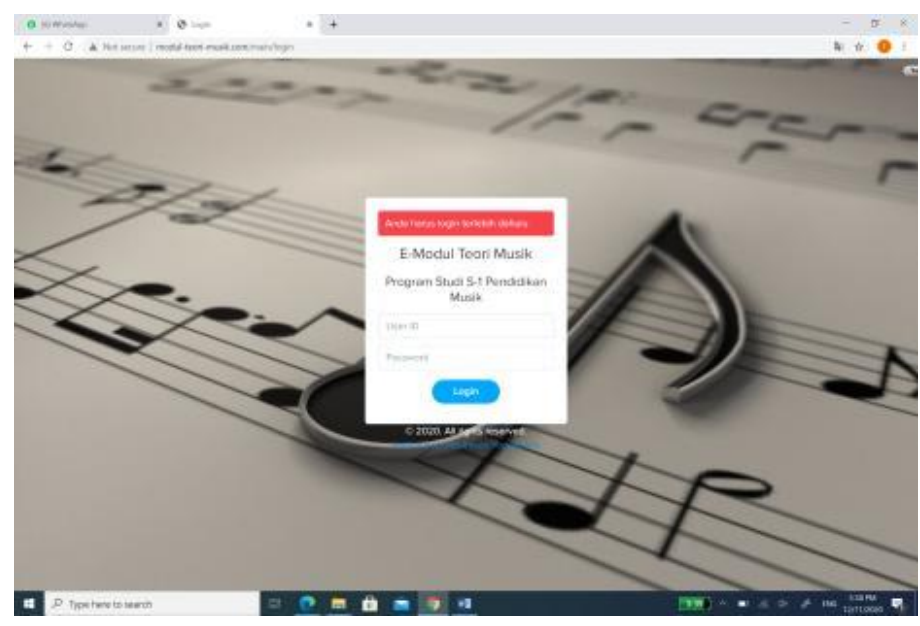

Figure 1. Login page display to access music theory e-module

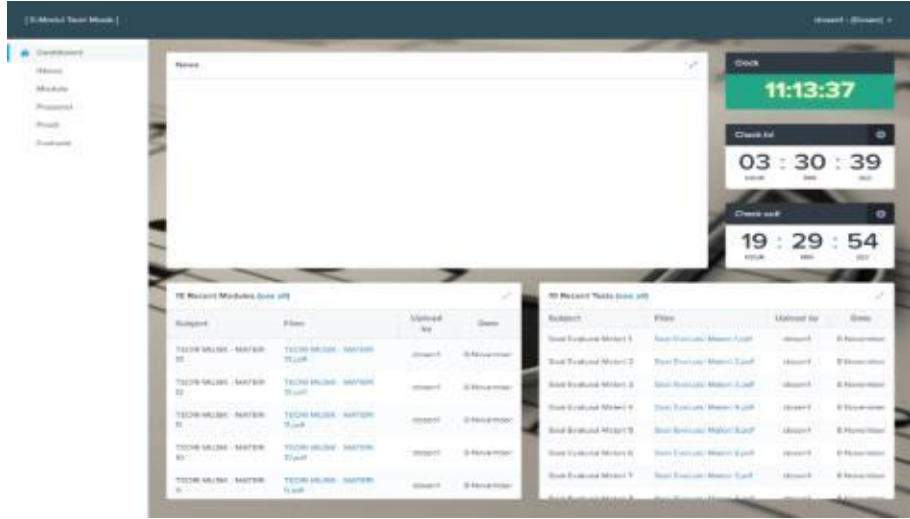

Figure 2. Web display of theory music e-modules

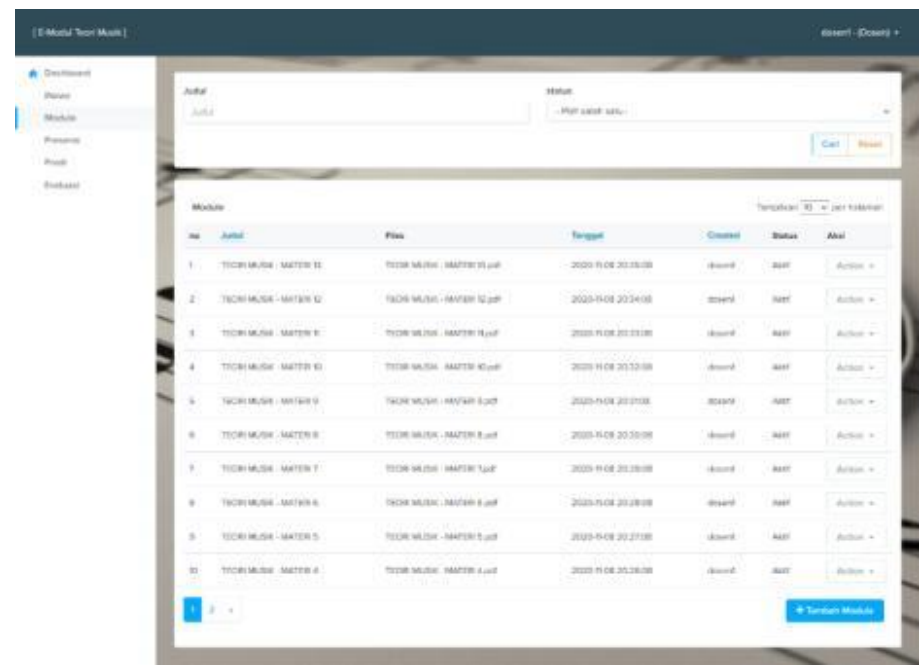

Figure 3. Module display menu 


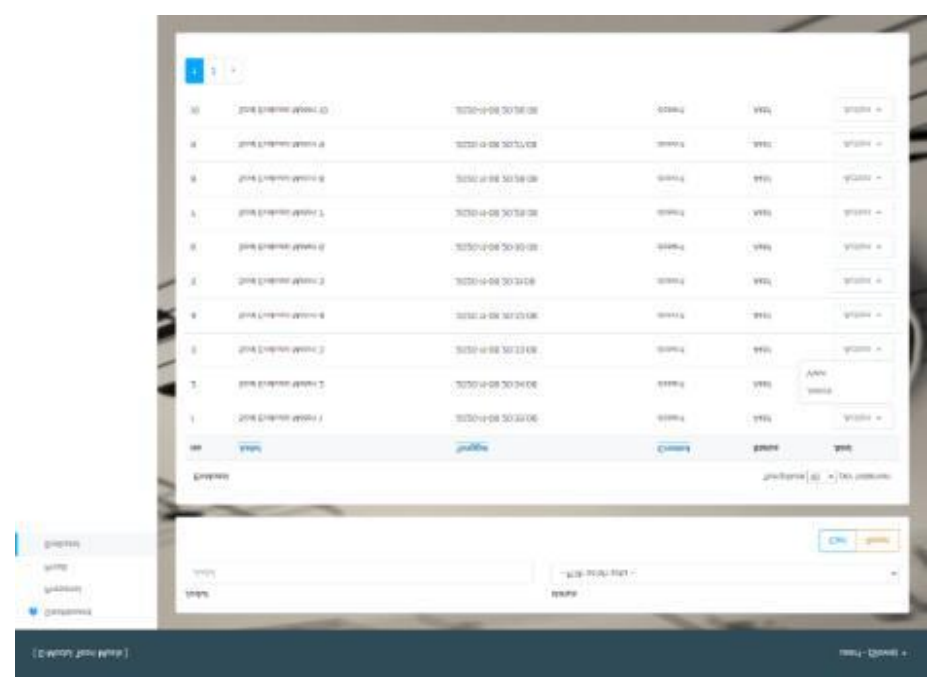

Figure 4. Evaluation menu display

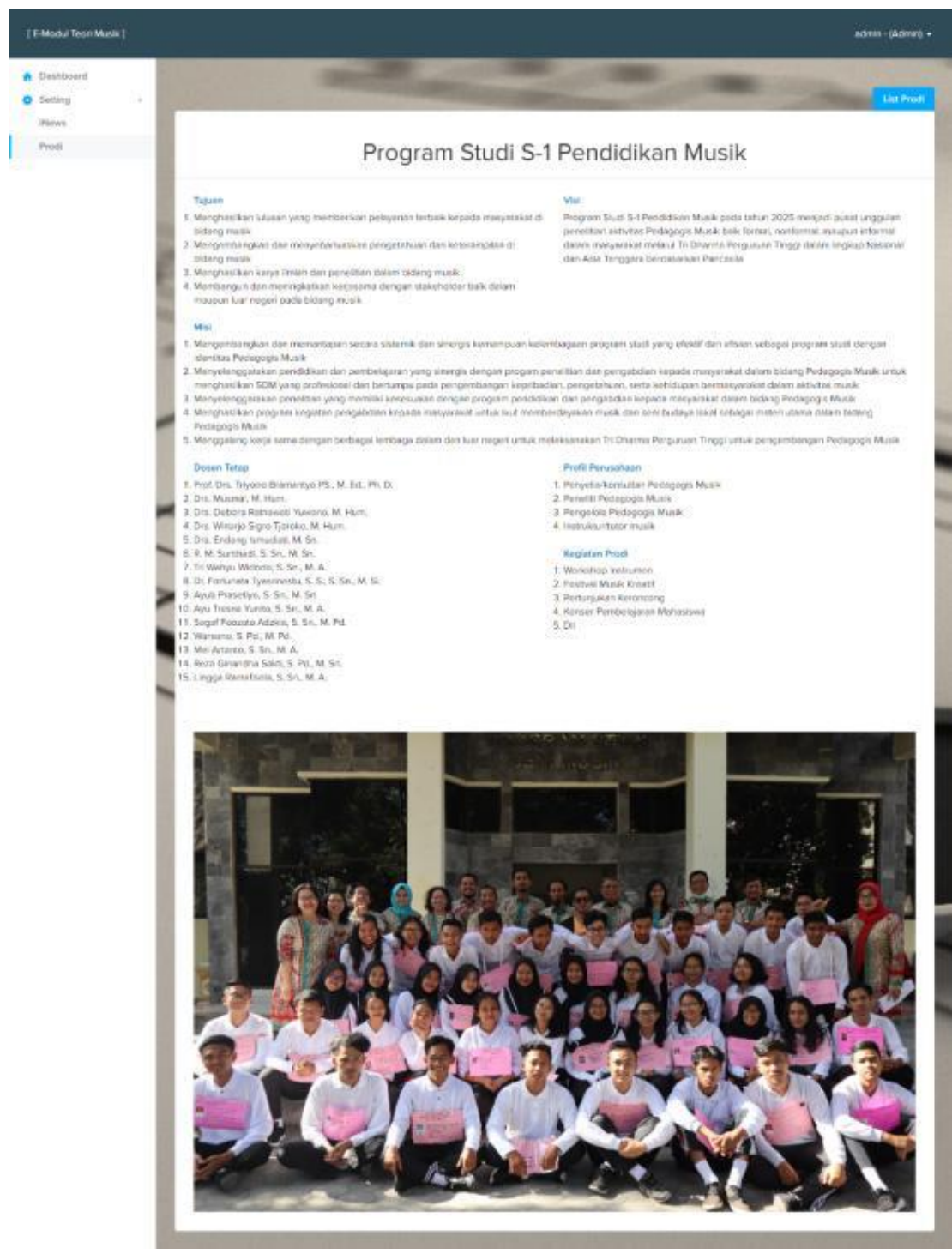

Figure 5. Display menu of Department of Music Education Profile 
The first figure is the home page look of the web to get into the music modules where a user is required to input his/her username and password. Meanwhile, the second figure shows the content of the web in which a user can access the music theory modules anywhere and anytime. The results of the research on digitized music theory modules are presented in the two figures above. From 20 students who were used as research sample, the researcher got the interview result that students agreed with digitization of music theory modules because it could make easier in learning music theory. Besides, lecturers felt the benefit of the web-based music theory modules because they can update the learning materials quickly and so can manage the time more effectively.

\section{Conclusion}

Based on the research results, the digitization of web-based music theory modules is one of the proofs of digital transformation due to technological advancement. The digitization process of music theory modules aims to put the students and lecturers at ease in conducting the teaching-learning activity for music theory classes. By having the web-based modules, students can learn by only using their phones anytime and anywhere. The benefit of digitizing the web-based music theory modules for lecturers who teach music theory classes is that they can quickly update or add relevant information on the web. As a consequence, website maintenance must be done regularly to make users, including students and lecturers, able to continuously access the web. Overall, this research was done well and could accomplish the goals, such as to digitize the web-based music theory modules and to know the positive impacts on both lecturers and students who involve in music theory classes.

\section{References}

Asaniyah, N. (2017). Pelestarian Informasi Koleksi Langka: Digitalisasi, Restorasi, Fumigasi. Buletin Perpustakaan, 57, 85-94.

Baum, F., Newman, L., \& Biedrzycki, K. (2014). Vicious cycles: Digital technologies and determinants of health in Australia. In Health Promotion International. https://doi.org/10.1093/heapro/das062

Beaunoyer, E., Dupéré, S., \& Guitton, M. J. (2020). COVID-19 and digital inequalities: Reciprocal impacts and mitigation strategies. Computers in Human Behavior. https://doi.org/10.1016/j.chb.2020.106424

Bhat, A. (2016). Qualitative research (methods and examples). Www.Questionpro/Com. https://www.questionpro.com/blog/qualitative-research-methods/

Bloomberg, J. (2018). Digitization, Digitalization, And Digital Transformation: Confuse Them At Your Peril. Forbes. $\quad$ https://www.forbes.com/sites/jasonbloomberg/2018/04/29/digitization-digitalization-anddigital-transformation-confuse-them-at-your-peril/\#4c316f $3 \mathrm{e} 2 \mathrm{f} 2 \mathrm{c}$

Brown, B. C. (2010). How To Build Your Own Website With Little or No Money: The Complete Guide for Business and Personal Use. Atlantic Publishing Group Inc.

Crittenden, W. F., Biel, I. K., \& Lovely, W. A. (2019). Embracing Digitalization: Student Learning and New Technologies. Journal of Marketing Education. https://doi.org/10.1177/0273475318820895

Hariyanto, A. (2015). Membuat Web Profil Sekolah + PPDB Online. In Yogyakarta: Lokomedia. Lokomedia.

Harminingtyas, R. (2014). Analisis Layanan Website Sebagai Media Promosi, Media Transaksi dan Media Informasi dan Pengaruhnya Terhadap Brand Image Perusahaan pada Hotel Ciputra Di kota Semarang. Jurnal STIE Semarang, 11(44), 129-141. http://fsctold.modares.ac.ir/article_10614_30aea192f59914fbe55c62ccc37ee440.pdf

Hennink, M., Hutter, I., Bailey, A. (2020). Qualitative Research Methods. Sage Publications Ltd.

Indra, I. (2019). Apa Itu DNS? Pengertian, Fungsi, Cara Kerja, dan Cara Settingnya. Niagahoster. niagahoster.co.id/blog/apa-itu-dns/

Kawulich, B. B. (2005). Participant observation as a data collection method. Forum Qualitative Sozialforschung. https://doi.org/10.17169/fqs-6.2.466

Lestari, I. (2013). Pengembangan Bahan Ajar Berbasis Kompetensi. Padang: Akademia Permata.

Lust, G., Juarez Collazo, N. A., Elen, J., \& Clarebout, G. (2012). Content Management Systems: Enriched learning opportunities for all? In Computers in Human Behavior. https://doi.org/10.1016/j.chb.2011.12.009 
Marshall, C., \& Rossman, G. B. (1999). Designing qualitative research. 3rd edition. In Thousand Oaks.

Nasiri, M., Ukko, J., Saunila, M., Rantala, T. (2020). Managing the digital supply chain: The role of smart technologie. Technovation, 96-97.

Oztaysi, B. (2014). A decision model for information technology selection using AHP integrated TOPSIS-Grey: The case of content management systems. Knowledge-Based Systems. https://doi.org/10.1016/j.knosys.2014.02.010

Pangrazio, L., Godhe, A. L., \& Ledesma, A. G. L. (2020). What is digital literacy? A comparative review of publications across three language contexts. E-Learning and Digital Media. https://doi.org/10.1177/2042753020946291

Putra, A. D., Putra, I. E. D., \& Ferdian, R. (2019). Pengembangan Modul Pembelajaran Teori Musik Pada Prodi Pendidikan Musik Fakultas Bahasa Dan Seni Universitas Negeri Padang. Musikolastika: Jurnal Pertunjukan Dan Pendidikan Musik. https://doi.org/10.24036/musikolastika.v1i1.15

Raco, J. . (2010). Metode Penelitian Kualitatif: Jenis, Karakteristik,, dan Keunggulannya. In Jakarta: Grasindo.

Reddy, S., Herring, S., \& Gray, A. (2017). Identifying an appropriate Content Management System to develop Clinical Practice Guidelines: A perspective. In Health Informatics Journal. https://doi.org/10.1177/1460458215616264

Ritter, T., Pedersen, C. L. (2020). Digitization capability and the digitalization of business models in business-tobusiness firms: Past, present, and future. Industrial Marketing Management, 86(Digitization capability and the digitalization of business models in business-to-business firms: Past, present, and future), 180190.

Ruhiat, Y., \& Djumena, I. (2019). Pengembangan Bahan Ajar Digital pada Mata Pelajaran Dasar Listrik dan Elektronika Kelas X ( The Development of Digital Teaching Materials In Electrical And Electronic Basic Learning Class X ). Jurnal Teknologi Pendidikan Dan Pembelajaran, 6(November), 156-168.

Schwars, M. (2020). Covid 19 and the academy: It is time for going digital. Energy Research \&Social Science, 68.

Setiawan, E. (2019). digitalisasi @ kbbi.web.id. KBBI Daring. https://kbbi.web.id/digitalisasi

Sugiyono. (2014). Metode Penelitian Pendidikan pendekatan Kuantitatif, Kualitatif dan R\&D. In Bandung:Alfabeta.

Suryoso; S, N. (2014). Pengembangan Modul Elektronik Berbasis Web Sebagai Media Pembelajaran Fisika. Jurnal Kependidikan, 43(1), 73-82. https://doi.org/10.21831/jk.v44i1.2193

Website.com. (2019). What is Web Hosting? https://www.website.com/beginnerguide/webhosting/6/1/what-isweb-hosting?.ws

Yen, Chia-Chen., Yen, C., Hsu, J.-S. (2008). A Web-based CMS/PDM Integration for Product Design and Manufacturing. IEEE International Conference on E-Business Engineering.

Yuhefizar. (2012). Cara Mudah dan Murah Membangun dan Mengelola Website. Yogyakata: Graha Ilmu. In Yogyakarta: Graha Ilmu. 